\title{
PERILAKU KONSUMEN DALAM PERSPEKTIF EKONOMI ISLAM
}

\author{
Suharyono \\ STIESNU Bengkulu \\ Email :haryonokpm05@gmail.com
}

\begin{abstract}
Human Resources in everyday life will never be separated by the fulfillment of needs or consumption. Islamic economics provides a picture and guidance in terms of consumption is justified and required in Islamic teachings that are guided by the rules of Shari'a. An item or commodity which is actually allowed to be used or consumed can be something that can be contrary to sharia depending on the behavior in using the goods or commodities. It can be concluded that consumption in Islam is loaded with spiritual values that indirectly lead consumers to avoid consumptive and keep the benefit is not just pleasure and satisfaction.
\end{abstract}

Keyword: Consumer Behavior, Motivation, Islamic Economics

Abstrak : Sumber Daya Manusia dalam kehidupan sehari-hari tidak akan pernah terlepas dengan pemenuhan kebutuhan atau konsumsi. Ekonomi islam memberikan gambaran dan pedoman dalam hal konsumsi yang dibenarkan dan di syaratkan dalam ajaran Islam yang berpedoman kepada aturan syariat. Suatu barang atau komoditas yang sebenarnya diperbolehkan untuk digunakan ataupun dikonsumsi bisa menjadi sesuatu yang dapat bertentangan dengan syariat tergantung dengan perilaku dalam menggunakan barang atau komoditas tersebut. Dapat disimpulkan bahwa konsumsi dalam Islam sarat dengan nilai-nilai kerohanian yang secara tidak langsung mengarahkan konsumen agar tidak konsumtif dan tetap menjaga kemaslahatan bukan kesenangan dan kepuasan semata.

Kata Kunci: Perilaku Konsumen, Motivasi, Ekonomi Islam

\section{A. PENDAHULUAN}

Dalam kehidupan sehari-hari setiap insan tidak bisa terlepas dari tindakan atas pemenuhan kebutuhan atau yang lebih dikenal dengan kegiatan konsumsi. Konsumsi adalah menghabiskan atau menggunakan suatu nilai barang atau jasa. Menurut ilmu ekonomi, konsumsi adalah setiap kegiatan memanfatkan, menghabiskan kegunaan barang dan jasa untuk memenuhi kebutuhan dalam upaya menjaga kelangsungan hidup. ${ }^{1}$ Jadi dalam hal ini bukan hanya sekedar mementingkan kesenangan, kepuasan semata melainkan mengkonsumsi suatu barang/jasa karna

\footnotetext{
${ }^{1}$ Sukarno Wibowo, Ekonomi Mikro Islam (Bandung: Pustaka Setia, 2013), hal. 225.
}

memang barang tersebut sudah sewajarnya untuk dipenuhi. Kaitannya dalam hal perilaku, setiap insan mempunyai cara atau perilaku yang berbeda dalam hal melakukan tindakan konsumsi. Banyak faktor yang bisa melatarbelakangi perilaku konsumsi diantaranya yang bersumber dari motivasi internal dan eksternal. motivasi internal bersumber dari kepribadian secara individu seperti karakter baik yang ada dalam individu tersebut. sedangkan motivasi eksternal dapat bersumber dari budaya lingkungan sosial, dunia pendidikan dan faktor eksternal lainnya yang dapat mempengaruhi individu dalam melakuakan suatu tindakan. 
Islam sebagai landasan utama setiap muslim juga mengatur akan tindakan mengkonsumsi suatu barang/jasa. Contoh dari aturan syariat seperti manusia dilarang untuk mengkonsumsi barang yang sudah jelas diharamkan untuk dikonsumsi, berlebih-lebihan, gaya hidup hedonisme yang mementingkan kesenangan dan kemewahan semata, berpoya-poya/ boros dan perilaku lainnya yang dilarang oleh Islam. Tulisan ini membahas tentang apa itu perilaku konsumen, faktor-faktor yang mempengaruhi perilaku konsumen, serta mengkaji perilaku konsumen dalam sudut pandang ekonomi yang berlandaskan atas syariat Islam.

\section{B. Perilaku Konsumsi}

\section{Pengertian Perilaku Konsumsi}

Perilaku konsumsi adalah bagian dari tindakan konsumsi. Perilaku yaitu tanggapan atau reaksi individu yang terwujud dalam gerakan (sikap), tidak saja badan atau ucapan. $^{2}$ Perilaku didasari oleh berbagai faktor baik dalam diri pribadi secara internal maupun dari faktor luar. Perilaku yang bersumber dari dalam diri sendiri adalah perilaku yang memang sudah ada sejak lahir dan

${ }^{2}$ Departemen Pendidikan dan Kebudayaan, Kamus Besar Bahasa Indonesia, (Jakarta: Balai Pustaka, 1990) hal. 671 semakin terbentuk dengan adanya pembentukan karakter/sifat yang ditanamkan oleh lingkungan terdekat seperti keluarga. Perilaku yang dipengaruhi oleh faktor eksternal adalah perilaku yang terbentuk karna adanya pengaruh dari luar seperti lingkungan sosial dan masyarakat. Perilaku seseorang yang baik salah satunya terbentuk karena memang mendapatkan arahan dan pelajaran dari faktor luar. Dalam contoh kasus, seseorang yang memiliki perilaku yang baik biasanya sering berkumpul dan berada dalam lingkungan yang baik pula. Istilah "jika ingin menjadi wangi maka seringseringlah berkumpul dengan orang penjual parfum”.

Konsumsi adalah menghabiskan atau menggunakan suatu nilai barang atau jasa. Menurut ilmu ekonomi, konsumsi adalah setiap kegiatan memanfatkan, menghabiskan kegunaan barang dan jasa untuk memenuhi kebutuhan dalam upaya menjaga kelangsungan hidup. ${ }^{3}$ Jadi dalam hal ini bukan hanya sekedar mementingkan kesenangan, kepuasan semata melainkan menkonsumsi suatu barang/jasa karna

${ }^{3}$ Sukarno Wibowo, Ekonomi Mikro Islam (Bandung: Pustaka Setia, 2013), hal. 225. 
memang barang tersebut sudah sewajarnya untuk dipenuhi.

Perilaku konsumsi adalah tindakan yang langsung terlibat dalam mendapatkan, mengkonsumsi, dan menghabiskan produk atau jasa, termasuk proses keputusan yang mendahului dan menyusuli tindakan ini. ${ }^{4}$ Dengan kata lain adalah bisa dikatakan dengan cara melakukan suatu tindakan konsumsi.

Cara dalam hal ini ada dua kemungkinan yaitu cara yang baik dan cara yang tidak baik atau tidak dibenarkan. Cara yang baik akan berlandaskan kebenaran dan sesuai dengan aturan baik secara hukum positif dan aturan syariat Islam. cara yang yang tidak baik(buruk) hanya akan berlandaskan keinginan semata tanpa batasan aturan yang ada.

Perilaku konsumen dalam pengertian lain adalah perilaku yang ditunjukkan konsumen dalam mencari, menukar, menggunakan, menilai, mengatur barang atau jasa yang dianggap mampu memuaskan kebutuhan

${ }^{4}$ Nugroho J. Setiadi, Perilaku Konsumen perspektif Kontemporer pada motif, tujuan, dan Keinginan Konsumen (rev.ed; Jakarta: Kencana Prenada Media Group 2010), hal. 2. mereka. ${ }^{5}$ Perilaku konsumen juga berarti cara konsumen mengeluarkan sumberdayanya yang terbatas, seperti uang, waktu, dan tenaga untuk mendapatkan barang atau jasa yang diinginkan demi kepuasannya.

Perilaku yang dilakukan antar konsumen tentu akan beragam sesuai dengan kondisi konsumen, situasi dan kondisi eksternal yang mempengaruhinya. ${ }^{6}$ Perilaku seseorang dalam melakukan tindakan konsumsi tersebut diharapkan dapat tetap sesuai dengan batasan-batasan yang telah di tetapkan, baik dari segi kesehatan, aturan hukum dan terutama aturan syariat yang menjadi landasan utama setiap muslim dalam melakukan suatu tindakan.

Penelitian yang dilakukan oleh Rama Doni 7 tahun 2014 pada penelitiannya yang berjudul "Tinjauan ekonomi Islam terhadap perilaku konsumen dalam membeli barang di pasar panorama Zahara Busana Kota

\footnotetext{
${ }^{5}$ Sukarno Wibowo, Dedi supriadi, Ekonomi Mikro...,hal. 235.

${ }^{6}$ Tatik suryani,Perilaku konsumen di era internet, (Yogyakarta: Graha Ilmu, 2013), hal. 5

7 Rama Doni, “ Tinjauan Ekonomi Islam Terhadap Perilaku Konsumen dalam Membeli Barang Di Pasar Panorama Zahara Busana Kota Bengkulu", skripsi pada Jurusan Ekonomi Islam tahun 2014.
} 
Bengkulu" menggunakan metode deskriptif kualitatif menyimpulkan bahwa tinjauan ekonomi Islam terhadap perilaku konsumen dalam membeli barang di pasar panorama adalah bahwa itu sesuai dengan aturan yang harus diteliti oleh seseorang dalam membeli barang dan sesuai dengan prinsip syariat islam. Seperti dengan cara konsumen dalam membeli barang tidak boleh boros dalam membeli barang.

Perilaku konsumen dapat dipahami dalam tiga tahapan. Pertama: Preferensi konsumen. Ini adalah langkah pertama untuk menjelaskan alasan seseorang yang lebih suka suatu jenis produk daripada jenis produk yang lain. Kedua: Garis anggaran. Konsumen juga akan mempertimbangkan faktor harga dan akan memutuskannya sesuai dengan pendapatan yang dimiliknya. Ketiga: Pilihan konsumen. Dengan mengtetahui preferensi dan keterbasan pendapatan yang dimiliki, konsumen memilih untuk membeli kombisi barang-barang yang memaksimalkan kepuasan mereka. Kombinasi ini akan bergantung pada harga berbagai barang tersebut. ${ }^{8}$

8 M.Nur Rianto, Euis Amalia, Teori Mikro Ekonomi Suatu Perbandingan Ekonomi Islam dan

\section{Faktor-faktor Yang Mempengaruhi} Perilaku Konsumen

Merujuk pada pendapat Hawkins dan Mothersbaugh, perilaku konsumen merupakan studi tentang bagaimana individu, kelompok dan organisasi serta proses yang dilakukan untuk memilih, mengamankan, menggunakan dan menghentikan produk, jasa, pengalaman atau ide untuk memuaskan kebutuhannya dan dampaknya terhadap konsumen dan masyarakat. ${ }^{9}$

Seperti yang telah sedikit dipaparkan di awal faktor-faktor yang mempengaruhi perilaku konsumen yaitu "faktor eksternal dan faktor internal. Faktor eksternal merupakan faktor yang meliputi pengaruh keluarga, kelas sosial, kebudayaan, strategi merketing, dan kelompok referensi. Kelompok referensi merupakan kelompok yang memiliki pengaruh langsung ataupun tidak langsung pada sikap dan perilaku konsumen. Kelompok ini mempengaruhi perilaku seseorang dalam pembelian dan sering dijadikan pedoman oleh konsumen dalam bertingkah laku.

Ekonomi Konvensional (Jakarta: Kencana Prenada Group, 2010), hal. 91

${ }^{9}$ Tatik suryani,Perilaku konsumen di era..., hal. 6 
Dalam kasus seperti sekarang ini dengan kemajuan tekhnologi dan media masa terutama media online sangat mudah sekali bisa mempengaruhi perilaku konsumen. Gaya hidup orang asing yang kurang baik mudah sekali untuk terakses dan secara tidak langsung akan mempengaruhi pola perilaku orang yang mengaksesnya. Kehidupan yang glamor, hedonis seorang artis misalnya, dapat diakses dengan mudah dan bagi penggemar yang tidak terfilter akan meniru gaya-gaya yang tidak baik tersebut. Tindakan yang memaksakan diri sangat mungkin untuk dilakukan agar keinginannya tersebut dapat terpenuhi, misalnya melakukan tindakan pencurian, penipuan dan melakukan bisnis yang di larang baik secara undang-undang maupun aturan agama.

Faktor internal yang mempengaruhi perilaku konsumen, yaitu motivasi, persepsi, gaya hidup, kepribadian, dan belajar." ${ }^{10}$ Perilaku dari setiap individu akan berbeda sesuai dengan karakteristik dan sifat yang ada dalam diri masingmasing. Faktor ini terbentuk secara alamiah yang mendorong dirinya untuk melakukan suatu tindakan. Kesadaran Mikro...,hal. 235. diri menjadi ciri utama dari perilaku yang bersumber dari internal diri seseorang dengan wujud perilaku baik. Begitu juga sebaliknya ketidaksadaran dalam diri seseorang yang cenderung negatif akan memunculkan perilaku yang jelek pula.

\section{Perilaku Konsumsi Dalam Ekonomi Islam}

Dalam Islam, konsumsi tidak dapat dipisahkan dari peranan keimanan. Peranan keimanan menjadi tolak ukur penting karena keimanan memberikan cara pandang dunia yang cenderung mempengaruhi kepribadian manusia. Keimanan sangat mempengaruhi kuantitas dan kualitas dan konsumsi, baik dalam bentuk kepuasan materil maupun spiritual. Dalam Islam juga sudah sangat jelas dijelaskan tentang aturan dalam melakukan segala perbuatan, baik buruk, halal haram yang termaktub dalam Alqu'an, Hadis dan ijma ulama.

Nilai dasar yang menjadi fondasi bagi perilaku konsumsi masyarakat muslim adalah keyakinan terhadap adanya hari kiamat dan kehidupan akhirat, kebajikan,kebenaran dan ketakwaan kepada Allah SWT 
merupakan kunci moralitas Islam. kebajikan dan kebenaran dapat dicapai dengan perilaku yang baik dan bermanfaat bagi kehidupan dan menjauhkan diri dari kejahatan, harta merupakan alat untuk mencapai tuuan hidup jika diusahakan dan dimanfaatkan dengan benar. ${ }^{11}$

Perilaku konsumsi orang yang beriman akan berbeda dalam mengkonsumsi barang/jasa jika di bandingkan dengan orang yang lebih rendah tingkat keimanan dan kepatutannya kepada Allah SWT. Orang yang mempunyai keimanan dan patuh terhadap aturan-aturan yang telah di gariskan didalam Al-Qur'an dan hadits mengetahui batasan-batasan mana hal yang diperbolehkan dan mana yang tidak boleh untuk di laksanakan.

Jika kebutuhannya sudah dirasa cukup maka konsep berbagi kepada sesama akan ikut serta dilaksanakan. Melhat lingkungan sekitar yang masih banyak masyarakat yang mengalami kekurangan atas kebutuhan dan memberikan bantuan dan bimbingan agar kedepannya bisa memenuhi kebutuhannnya secara mandiri. Dengan

11 Vinna Sri, Ekonomi Mikro syariah, (Bandung: Pustaka Setia, 2016), hal. 86. kata lain tidak mengoptimalkan kebutuhan dan keinginan pribadi.

Berbagai kegiatan ekonomi berjalan dalam rangka mencapai satu tujuan, yakni menciptakan kesejahteraan menyeluruh, penuh ketegangan dan kesederhanaan, namun tetap produktif dan inofatif bagi setiap individu muslim maupun non muslim. Allah telah menetapkan batasan-batasan terhadap perilaku manusia sehingga menguntungkan individu tanpa mengorbankan hak-hak individu lainnya, sebagaimana yang ditetapkan dalam hukum Allah (syari'ah).

Islam mengajarkan tentang batasan-batasan manusia dalam mengkonsumsi suatu produk barang atau jasa, baik yang dijelaskan dalam AlQur'an maupun hadis. Kesejahteraan konsumen akan meningkat jika ia banyak mengkonsumsi barang yang bermanfaat, halal, dan mengurangi barang yang buruk atau haram. Islam melarang untuk menghalalkan apa yang sudah ditetapkan haram dan memgharamkan apa-apa yang sudah menjadi halal.

Dalam Al-Qur'an disebutkan :

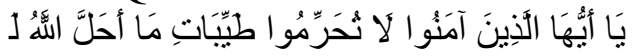

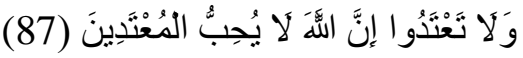




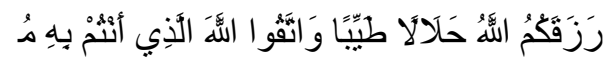

"Hai orang-orang yang beriman, janganlah kamu mengharamkan apaapa yang baik yang telah Allah halalkan bagi kamu, dan janganlah kamu melampaui batas. Dan makanlah makanan yang halal lagi baik dari apa yang Allah telah rezkikan kepadamu, dan bertakwalah kepada Allah yang kamu beriman kepada-Nya." ${ }^{12}$ (Qs. AlMa'idah :87-88)

Ayat tersebut Al Qur'an mendorong manusia sebagai pengguna untuk menggunakan barang-barang yang baik dan bermanfaat serta melarang adanya tindakan yang mengacu dalam hal perilaku boros dan pengeluaran terhadap pengeluaran yang tidak penting dan tidak bermanfaat. Sesungguhnya kuantitas konsumsi yang terpuji dalam kondisi yang wajar adalah sederhana. Maksudnya, berada diantara boros dan pelit. ${ }^{13}$ Artinya dalam hal pengeluaran kebutuhan juga yang mendatangkan manfaat kita tidak boleh pelit.

Misalnya memiliki kemampuan yang cuup untuk mengkonsumsi makanan yang bergizi seperti daging, susu namun tidak mengkonsumsinya dikarenakan karena alasan untuk ditabung sedangkan memiliki kemampuan yang lebih.

Allah SWT berfirman dalam AlQur'an.

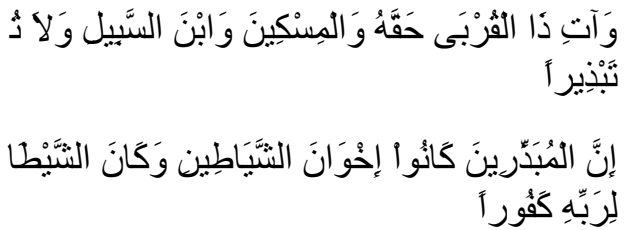

Dan berikanlah kepada keluargakeluarga yang dekat akan haknya, kepada orang miskin dan orang yang dalam perjalanan dan janganlah kamu menghambur-hamburkan (hartamu) secara boros.

Sesungguhnya pemboros-pemboros itu adalah saudara-saudara syaitan dan syaitan itu adalah sangat ingkar kepada Tuhannya.(QS Al- Isra’: 26-27)

Ayat tersebut secara tegas menjelaskan, daripada harta kita dipergunakan untuk hal-hal yang tidak berguna, tidak perlu atau tidak penting (yang Allah sebut sebagai perbuatan mubazir) akan lebih baik jika dipergunakan untuk membantu kerabat dekat, sanak famili, dan orang fakir miskin. Inilah manfaat prinsip efisiensi yang hanya bisa kita dapatkan dari menghindari sifat boros, prinsip mengejar kesenangan dan pola hidup

${ }^{12}$ Assobar, Al-Kitabul Akbar Al-Qur'an dan Terjemahannya (Jakarta Timur: Akbar Media), hal.122.

${ }^{13}$ Lukman Hakim, Prinsip-prinsip Ekonomi Islam (Erlangga, 2012), hal. 95. 
hedonisme. ${ }^{14} \quad$ Yang menjadi permasalahan adalah menganggap semua harta yang dimiliki adalah mutlak milik diri secara individu, disamping tidak memperhatikan lingkungan sekitar yang seharusnya mempunyai hak untuk mendapatkan bantuan juga akan sangat dimungkinkan melakukan tindakan konsumsi secara bebas tanpa adanya filter.

Pada saat melakukan tindakan konsumsi tersebut kemungkinan memang akan mendapatkan kesenangan dan kepuasan namun efek dari tindakannya tidak disadari akan mendatangkan keburukan bagi dirinya baik secara langsung maupun dimasa yang akan datang. Hal buruk yang bisa di dapat misalnya saat mengkonsumsi narkoba ditangkap oleh pihak kepolisian/BNN maka akan mendapatkan sanksi hukum, efek buruk di masa yang akan datang misalnya mengalami gangguan kesehatan, bahkan kematian secara duniawi dan tetap akan mendapatkan balasan di akhirat karna

\footnotetext{
${ }^{14}$ Misbahul Munir, Ajaran-ajaran Ekonomi Rasulullah kajian Hadits Nabi dalam Perspektif Ekonomi.(Uin Malang Press, Malang 2007), hal.75.
}

mengkonsumsi barang yang di larang agama.

Konsumsi, pemenuhan (kebutuhan), dan perolehan kenikmatan tidak dilarang dalam Islam selama tidak melibatkan hal-hal yang tidak baik atau justru dapat menimbulkan kemudharatan. ${ }^{15}$ Setiap orang mukmin berusaha mencari kenikmatan dengan cara mematuhi perintahNya dan memuaskan dirinya sendiri dengan barang-barang dan anugrah yang diciptakan (Allah) untuk manusia demi kemaslahatan ummat.

Selain kenikmatan yang didapat atas pemenuhan kebutuhannya ketenangan jiwa juga akan secara langsung didapatkan. Orang yang jiwanya tenang tidak akan menggebu-gebu dalam mencari harta dengan menghalalkan segala cara untuk mendapatkannya, melainkan tetap berusaha mencari rezeki dan keridhan Allah. Harta yang didapat dari jalan yang tidak di benarkan oleh ajaran Islam secara alamiah secara tidak langsung bisa mengakibatkan perilaku konsumsi yang salah pula. Berpoyapoya, membeli barang haram, dan lain sebagainya dikarenakan harta selain dari nikmat yang diberikan harta juga adalah

\footnotetext{
${ }^{15}$ M. Nur Rianto A. Euis Amalia, Teori Mikro Ekonomi Suatu Perbandingan..., hal.110.
} 
sebagai godaan yang cenderung kepada hal-hal negatif.

Konsumsi berlebih-lebihan, yang merupakan ciri khas masyarakat yang tidak mengenal Tuhan, dikutuk dalam islam dan disebut dengan israf (pemborosan) atau tabzir (menghamburhamburkan harta tanpa guna). ${ }^{16}$ Tabzir berarti menggunakan harta dengan cara yang salah seperti untuk hal yang tidak dibenarkan atau melanggar hukum terutama hukum Islam. Boros hampir sama dengan mubazir.

Mubazir adalah mengahamburhamburkan uang tanpa ada kemaslahatan atau tanpa mendapatkan ganjaran pahala. ${ }^{17}$ Masyarakat secara global dan khususnya di Indonesia baik dari kalangan remaja, dewasa dan orang tua sekarang ini sangat rentan sekali melakukan tindakan konsumsi terhadap barang-barang haram seperti Narkoba.

Narkoba tercatat sebagai salah satu unsur yang merusak jiwa pribadi seseorang dan orang lain. Hal ini tidak akan terjadi jika masyarakat terutama masyarakat muslim yang memiliki

${ }^{16}$ M. Nur Rianto A. Euis Amalia, Teori Mikro Ekonomi Suatu..., hal. 86-87.

${ }^{17}$ Yusuf Qardhawi, Norma dan Etika Ekonomi Islam, (Jakarta: Gema insani 2001), hal. 155. panduan dan landasan atas aturan agam yang tidak memperbolehkan terhadap tindakan konsumsi barang-barang haram tersebut.

Islam menganjurkan pola konsumsi dan penggunaan harta secara wajar dan berimbang yaitu pola konsumsi yang terletak diantara kekikiran dan pemborosan atau dengan kata lain tidak mementingkan kesenagan semata. Jika mempunyai kemampuan untuk mengkonsumsi suatu barang/jasa maka itu diperbolehkan dengan standar aturan syariat yang ada. tidak kikir dalam artian meskipun memiliki kemampuan untuk memenuhi kebutuhan tapi tidak mau memenuhinya dan terkesan menyiksa diri.

Dalam Al-Qur'an surat Thaahaa ayat 81 disebutkan

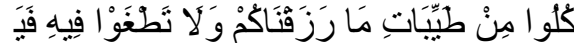

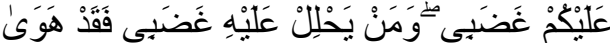

"makanlah di antara rezki yang baik yang telah Kami berikan kepadamu, dan janganlah melampaui batas padanya, yang menyebabkan kemurkaan-Ku menimpamu. dan Barangsiapa ditimpa oleh kemurkaan-Ku, Maka Sesungguhnya binasalah ia". ${ }^{18}$ (Qs. Thahaa: 81) 
Islam mengajarkan dalam mengkonsumsi suatu barang/jasa harus memperhatikan etika konsumsi yang mana yang dibenarkan dan mana yang tidak dibenarkan. Dalam ekonomi konvensional, manusia disebut rasional secara ekonomi jika mereka selalu memaksimumkan kepentingan sendiri, yaitu utility untuk konsumen dan keuntungan untuk produsen. Sementara itu dalam ekonomi Islam pelaku ekonomi, produsen atau konsumen, akan berusaha untuk memaksimalkan maslahat. ${ }^{19}$

Konsep utility oleh konsumen diukur dari kepuasan yang diperoleh dan keuntungan maksimal bagi produsen dan distributor sehingga berbeda tujuan yang akan dicapai dengan konsep maslahah.

Dalam Al-Quran kata maslahah banyak disebut dengan istilah manfaat atau manafi', yang berarti kebaikan yang berkaitan dengan material fisik, dan psikologis. Dengan kata lain maslahah mengandung pengertian kemanfaatan duniai dan akhirat. Konsep maslahah pada konsumen muslim sangatlah

${ }^{19}$ Pusat pengkajian dan Pengembangan Ekonomi Islam, Ekonomi Islam, (Jakarta: PT. Raja Grafindo Persada, 2011), hal. 46. diperlukan. Dalam pengertian umum maslahah adalah setiap segala sesuatu yang bermanfaat bagi manusia, baik dalam arti menarik seperti menghasilkan keuntungan (kesenangan), atau dalam arti menolak atau menghindarkan seperi menolak kerusakan. ${ }^{20}$ maslahah menurut Shatibi, adalah pemilikan atau kekuatan dari barang atau jasa yang memelihara prinsip dasar dan tujuan hidup manusia. 21

Menurut Al-Ghazali, kesejahteraan (maslahah) dari suatu masyarakat tergantung kepada pencarian dan pemeliharaan lima tujuan dasar : (1) agama (al-dien), (2) hidup atau jiwa (nafs), (3) keluarga atau keturunan (nashl), (4) harta atau kekayaan (maal) dan (5) intelek atau akal (aql). Ia menitikberatkan bahwa sesuai tuntunan wahyu, kebaikan dunia ini dan akhirat (maslahat al-din wa al-dunya) merupakan tujuan utamanya. ${ }^{22}$

Seorang muslim melakukan tindakan konsumsi untuk memenuhi

${ }^{20}$ Totok Jumantoro, Samsul Munir Amin, Kamus Ilmu Ushul Fikih, Amzah (Sinar Grafika Offset, 2005), hal. 200.

${ }^{21}$ M.Nur Rianto, Teori Mikro Ekonomi Suatu Perbandingan ..., hal. 91.

${ }^{22}$ Adiwarman Karim, Ekonomi Mikro Islam edisi ketiga (Jakarta: Raja Grafindo Persada, 2010), hal. 62. 
kebutuhan dengan harapan memperoleh kemanfaatan yang stinggi-tingginya bagi kehidupannya dengan tanpa melanggar aturan syariat Islam. Kebutuhan antara seseorang dengan seseorang lainnya ada kalanya berbeda yang dapat disebebkan oleh usia, kedudukan dan aspek eksternal lainnya.

Kebutuhan (need) merupakan konsep yang lebih bernilai dari sekedar keinginan (want). Want ditetapkan berdasarkan konsep utility yang cenderung lebih condong terhadap nafsu yang dapat menyesatkan kepada hal-hal yang dilarang syariat., need didasarkan atas konsep maslahah selagi itu baik dan mendatangkan mafaat maka itu diperbolehkan. Tujuan syariah adalah mensejahterahkan manusia (maslahah al 'ibad). ${ }^{23}$ Oleh karena itu setiap barang dan jasa yang memberikan maslahah bagi penggunanya di sebut dengan kebutuhan manusia yang secara tidak langsung memang harus di penuhi. Jika kebutuhan tersebut tidak terpenuhi maka seseorang tersebut akan mengalami kesusahan.

${ }^{23}$ M.Nur Rianto, Teori Mikro Ekonomi Suatu Perbandingan..., hal. 91.
Kebutuhan adalah fitrah setiap manusia yang bersifat obyektif dan mendatangkan manfaat dan kemaslahatan di samping kepuasan. Pemenuhan kebutuhan ini akan memberikan manfaat baik secara fisik, spiritual, intelektual maupun materil. Keinginan berasal dari hasrat manusia yang bersifat subyektif. Jika terpenuhi akan menimbulkan kepuasan atau manfaat psikis di samping manfaat lainnya. ${ }^{24}$

Ekonomi konvensional mengasumsikan konsumen selalu bertujuan untuk memperoleh kepuasan (utility),semua barang atau jasa yang akan memberikan rasa kepuasaan bebas untuk dikonsumsi dengan cara apapun tanpa adanya batasan kecuali batasan dari hukum positif yang mengatur pelanggaran terhadap aktivitas konsumsi suatu barang, misalnya konsumsi narkoba. sedangkan dalam ekonomi Islam dalam mengkonsumsi bertujuan untuk mencapai suatu maslahah.

Konsep maslahah digunakan dalam ekonomi Islam dikarenakan penggunaan asumsi manusia yang bertujuan untuk mencari kepuasan (utility) maksimum

\footnotetext{
${ }^{24}$ Vinna Sri, Ekonomi Mikro..., hal. 60.
} 
tidak dapat menjelaskan apakah barang yang dikonsumsinya memberikan manfaat dan kegunaan yang memberikan keberkahan bagi penggunanya. Dalam hal ini seseorang hanya dibatasi oleh dana/anggaran yang dimilikinya bukan karena aturan dan prinsip syariat Islam.

Formulasi dalam maslahah adalah unsur manfaat dan berkah, atau bisa ditulis sebagai berikut:

$$
\mathrm{M}=\mathrm{F}+\mathrm{B}
$$

Dimana: $\mathrm{M}=$ maslahah

$$
\begin{aligned}
& F=\text { Manfaat } \\
& B=\text { Berkah }
\end{aligned}
$$

Sementara berkah merupakan interaksi antara manfaat dan pahala, sehingga :

$$
\mathrm{B}=(\mathrm{F})(\mathrm{P})
$$

Dimana: $\mathrm{P}=$ Pahala total

Adapun pahala total, $\mathrm{P}$ adalah:

$$
\mathrm{P}=\beta \mathrm{i} \rho
$$

Dimana $\beta$ i adalah frekuensi kegiatan dan $\rho$ adalah pahala per unit kegiatan. Dengan mensubtitusikan persamaan diatas, maka

$$
\mathrm{B}=\mathrm{F} \beta \mathrm{i \rho} \text {. }
$$

Selanjutnya dengan melakukan subtitusi maka diperoleh:

$$
\mathrm{M}=\mathrm{F}+\mathrm{F} \beta \mathrm{i} \rho
$$

Persamaan diatas dapat ditulis menjadi:

$$
\mathrm{M}=\mathrm{F}(1+\mathrm{F} \beta \mathrm{i} \rho)
$$

Dari formulasi diatas dapat ditunjukkan bahwa ketika pahala suatu kegiatan tidak ada misalnya, ketika mengkonsumsi barang yang haram, maka maslahah yang diperoleh konsumen adalah hanya sebatas manfaat yang dirasakan di dunia $(\mathrm{F})$. Demikian pula sebaliknya, jika suatu kegiatan yang sudah tidak memberikan manfaat (di dunia), maka nilai keberkahannya juga tidak ada sehingga maslahah dari kegiatan tersebut juga tidak ada.

Besarnya keberkahan akan mengkonsumsi suatu barang dan jasa tergantung dengan frekuensi kegiatan konsumsi yang yang dilakukan. Semakin tinggi frekuensi kegiatan yang memberikan unsur maslahah maka akan besar pula keberkahan yang akan di dapat.

Preferensi konsumsi dan pemenuhan kebutuhan manusia memiliki pola berikut ${ }^{26}$ pertama, Mengutamakan Akhirat daripada Dunia.

${ }^{25}$ M.Nur Rianto, Teori Mikro Ekonomi Suatu Perbandingan...,hal. 101.

${ }^{26}$ Vinna Sri, Ekonomi M ikro..., hal. 68 
Pada tataran paling dasar konsumen muslim akan dihadapkan pada pilihan antara mengkonsumsi barang ekonomi yang bersifat duniawi dan benda yang bersifat ibadah. Konsumsi untuk beribadah bernilai lebih tinggi dibandingkan dengan konsumsi untuk duniawi sehingga keduanya bukan merupakan subtitusi sempurna. Misalnya mendengarkan kajian-kajian tentang keislaman dalam majelis. Konsumsi untuk ibadah diorientasikan untuk mencapai falah (kebahagiaan) sehingga lebih berorientasi pada kehidupan akhirat, sedangkan konsumsi duniawi adalah konsumsi untuk masa sekarang. Kedua, Konsisten dalam Prioritas Pemenuhan Kebutuhan. Prioritas kemaslahatan dibagi kedalam tiga tingkatan, yaitu maslahah dharuriyah, maslahah hajiyyah, dan maslahah tahsiniyyah. Maslahah dharuriyyah adalah kebutuhan yang harus segera dipenuhi agar kehidupan manusia tidak terganggu. Maslahah hajiyyah adalah kebutuhan yang jika dipenuhi akan meningkatkan nilai tambah. Adapun maslahah tahsiniyyah adalah kebutuhan yang jika terpenuhi akan menimbulkan kepuasan.
Ketiga, Memerhatikan etika dan norma. Dalam syariat Islam beberapa etika dan norma yang diatur berlandaskan Al-Quran dan As-Sunnah antara lain tentang keadilan, kebersihan, kesederhanaan, halalan tayyiban, dan keseimbangan.

Seseorang mengkonsumsi suatu barang atau jasa yang diniatkan untuk beribadah maka disamping hal itu nantinya akan mendatangkan manfaat akan diperoleh keberkahan bagi dirinya, sebagai contoh membeli dan berlangganan koran/surat kabar yang digunakan untuk kepentingan disini selain keberkahan yang bisa dirasakan oleh pelaku karena adanya suatu niat yang baik juga akan ada manfaat yang dirasakan oleh pelaku maupun orang lain yang membacanya seperti penambahan wawasan atau tentang info terbaru. Islam tidak melarang manusia untuk memenuhi kebutuhan ataupun keinginannya, selama dengan pemenuhan tersebut maka martabat manusia bisa meningkat, namun manusia diperintahkan untuk mengkonsumsi barang/jasa yang halal dan baik saja secara wajar serta tidak 
berlebihan. $^{27}$ Dengan kata lain melakukan kegiatan konsumsi yaitu dengan mengkonsumsi barang dengan kriteria baik barangnya, baik cara mengkonsumsinya dan mendatangkan manfaat bagi pengkonsumsinya.

\section{Motivasi}

\section{a. Pengertian Motivasi}

Motivasi berasal dari bahasa latin movore yang berarti dorongan atau menggerakkan atau dengan kata lain dapat diartikan sebagai sebab-sebab yang menjadi dorongan. Pentingnya motivasi adalah hal yang menyebabkan, menyalurkan, dan mendukung perilaku manusia." 28 Orang yang tidak memiliki motivasi dalam hidupnya adalah orang yang bisa dikatan hidup secara jasmani namun mati secara rohani. Motivasi akan berimplikasi terhadap tindakan dan proses yang akan dijalani. Motivasi dapat berimplikasi kepada tindakan yang baik dan yang buruk.

Menurut Hoy dan Miskel motivasi adalah kekuatan-kekuatan yang kompleks, dorongan-dorongan, kebutuhan-kebutuhan, pernyataanpernyataan, ketegangan, atau mekanisme-mekanisme lainnya yang memulai dan menjaga kegiatankegiatan yang diinginkan kearah pencapaian tujuan-tujuan personal atau pribadi.

Kata motivasi berarti dorongan yang timbul pada diri seseorang sadar maupun tidak sadar untuk melakukan suatu tindakan dengan tujuan tertentu. $^{29}$ Jika tujuan yang dikehendaki adalah suatu hal yang positif maka sumber motivasi itu juga adalah sebuah hal yang baik. Motivasi juga sering disebut sebagai usaha-usaha yang dapat menyebabkan seseorang maupun kelompok tertentu melakukan sesuatu kerena ingin mencapai tujuan yang dikehendakinya.

Seseorang konsumen tergerak membeli suatu produk karena ada sesuatu yang menggerakkan. Proses timbulnya dorongan sehingga konsumen tergerak membeli suatu produk itulah yang disebut motivasi.

${ }^{27}$ M.Nur Rianto, Teori Mikro Ekonomi Suatu Perbandingan..., hal.104.

${ }^{28}$ Nugroho J. Setiadi, Perilaku Konsumen perspektif..., hal.25.

${ }^{29}$ Tatik Suryani,Perilaku konsumen di era..., hal.22. 
Sedangkan yang memotivasi untuk membeli namanya motif. ${ }^{30}$

Motivasi dapat diartikan sebagai kekuatan (energi) seseorang yang dapat menimbulkan tingkat presistensi dan entusiasmenya dalam melaksanakan suatu kegiatan, baik yang bersumber dari dalam diri individu itu sendiri (motivasi intrinsik) maupun dari luar individu (motivasi ekstrinsik). Seberapa kuat motivasi yang dimiliki individu akan banyak menentukan terhadap kualitas perilaku yang ditampilkannya, baik dalam konteks belajar, bekerja maupun dalam kehidupan lainnya. ${ }^{31}$

Motivasi yang positif akan memunculkan tindakan-tindakan yang positif. Begitu juga sebaliknya motivasi yang negatif akan memunculkan tindakan-tindakan yang burk pula. Dalam sebuah kasus dicontohkan seseorang membeli "lem" dengan motivasi lem tersebut digunakan untuk mmperbaiki sepatu, hal.22.

${ }^{30}$ Tatik Suryani,Perilaku konsumen di era...,

${ }^{31}$ Abdul Rahman Saleh, Psikologi suatu pengantar dalam perspektif Islam(Jakarta:Prenada media kencana, 2004), hal. 128 maka itu adalah suatu tindakan yang positif dan memberikan maslahah.

Berbeda halnya dengan jika membeli "lem" dengan motivasi untuk mendapatkan kesenangan yang berkonotasi pada hal kejelekan, lem tersebut di konsumsi dengan cara di hirup dan berharap akan mendapatkan ketenangan. Tindakan tersebut dapat merusak diri pribadi, memberikan kemudharatan dan bahkan akan juga sangat dimungkinkan akan menyebabkan dampak negative bagi orang disekitarnya.

Motivasi dalam pengertian sehari-hari dapat diartikan sebagai sesuatu yang mendorong manusia untuk berperilaku tertentu. Motivasi adalah sesuatu yang ada di dalam diri manusia yang tidak dapat dilihat dari luar. Motivasi akan tampak melalui perilaku sesorang yang dapat dilihat dan diamati. Dari perilaku seseorang dapat dilihat dan diamati apa sebenarya yang menjadi motif atas tindakannya meskipun kebenarannya tidak bisa dipastikan secara penuh karna memang letaknya di dalam diri seseorang. 


\section{b. Sifat dan Fungsi Motivasi}

Pada umumnya motivasi atau kebutuhan manusia memiliki sifatsifat yaitu terdiri atas : kebutuhan tidak terpuaskan; Kebanyakan kebutuhan manusia tidak pernah terpuaskan sepenuhnya. Contoh seorang konsumen yang memiliki kebutuhan mobilitas, setelah mampu membeli barang yang biasa, timbul keinginannya untuk membeli barang yang lebih dari yang dibeli sebelumnya dan begitu seterusnya. Secara karakteristik memang kepuasan seseorang akan selalu mengalami peningkatan terutama jika di dukung dengan kemampuan yang ada.

Kebutuhan baru muncul setelah kebutuhan lama terpenuhi. Misalnya dahulu mempunyai sepeda motor dan sekarang dengan kemampuan yang ada dimungkinkan untuk membeli mobil yang didasarkan juga atas kebutuhan.

Selain itu Fungsi motivasi dapat dijelaskan antara lain adalah mendorong manusia untuk berbuat dan bertindak. Motivasi berfungsi sebagai penggerak yang memberikan energi (kekuatan) kepada seseorang untuk melakukan suatu tugas, menentukan arah perbuatan. Yakni kearah perwujudan suatu tujuan atau cita-cita. Motivasi mencegah penyelewengan dari jalan yang harus ditempuh untuk mencapai tujuan itu dan menyeleksi perbuatan kita. Artinya menentukan perbuatanperbuatan mana yang harus dilakukan, yang serasi, guna mencapai tujuan itu dengan menyampingkan perbuatan yang bermanfaat bagi tujuan itu. ${ }^{32}$

\section{c. Klasifikasi Motivasi}

Motivasi secara garis besar dapat dibagi menjadi dua kelompok besar, antara lain motivasi yang berdasarkan rasional dan motifasi yang berlandaskan emosional.

Motivasi yang berdasarkan rasional yaitu motivasi yang menentukan suatu pilihan terhadap suatu produk barang atau jasa dengan memikirkan secara matang serta dipertimbangkan terlebih dahulu untuk membeli produk atau jasa tersebut. Rasional motif akan

${ }^{32}$ Ngalim Purwanto, Psikologi Pendidikan(Jakarta: PT Remaja Rosdakarya, 2006), hal. 70. 
mendorong seseorang untuk bertindak menurut pikiran yang sehat, patut, layak. ${ }^{33}$ Melaku8kan suatu tindakan dengan memikiran akibat yang ditimbulkan adalah pengertian secara singkat terkait motivasi secara rasional.

Motivasi yang berlandaskan emosional yaitu motivasi yang cenderung terkesan terburu-buru, tidak mempertimbangkan kemungkinan yang akan terjadi untuk jangka panjang dalam menggunakan produk atau jasa tersebut. Di era zaman yang semakin berkembang seperti sekarang ini banyak sekali barang-barang yang dapat di kategorikan hanya untuk memenuhi kesenangan semata tanpa memperhatikan mudharat yang ditimbulkan.

Produksi barang dan tekhnologi yang di ciptakan memberikan dampak yang negatif bagi konsumen jika tidak didasari dan dilandasi atas aturan syariat. Misalnya dengan diciptakannya tekhnologi smartphone yang saat sekarang bisa dikatakan mayoritas dimiliki oleh orang, baik

\footnotetext{
${ }^{33}$ Nugroho J. Setiadi, Perilaku Konsumen perspektif..., hal. 35 .
}

dari kalangan anak-anak kecil sampai orang tua. Jika tidak dilandasi dan diawasi dan merasa ada yang mengawasi setiap tindakan yang dilakukan setiap individu sangat dimungkinkan akan melakukan tindakan konsumsi yang mengarah kepada hal keburukan. Misalnya mengakses video dewasa, melakukan penipuan, kejahatan dan lain sebagainya.

\section{d. Macam-macam motivasi}

Menurut ahli psikologi individual maupun sosial/kelompok telah melakukan studi tentang seberapa banyak dorongan-dorongan kejiwaan yang mempengaruhi tingkah laku manusia. Dengan nama yang berbeda-beda bagi adanya dorongandorongan tersebut antara lain: ${ }^{34}$ Motivasi yang mendorong aktivitas pribadi yang disebut Goldstein selfactualization yang bersifat organis (jasmania) dan psikologis (rohaniah). Motivasi ini menuntut kepada pemuas hidup jasmaniah serta pemuas rohaniah. Motivasi kepada keamanan atau security movie.

34 Arifin, Psikologi Dakwah Suatu Pengantar Islam (Jakarta: PT. Raja Grafindo Persada, 2009), hal. 59-63 
Motivasi ini dipandang oleh ahli psikologi sebagai yang paling asasi. Motivasi ini mengandung keinginankeinginan yang didasarkan atas kebutuhan seseorang untuk melindungi keinginan-keinginan yang didasarkan atas kebutuhan seseorang untuk melindungi dirinya dari segala bentuk ancaman terhadap integritas dan stabilitas hidupnya. Manifestasinya adalah dalam bentuk pengindraan dari bahaya dan resiko, juga dalam sikap hati-hati atau waspada. Motivasi untuk mengadakan response. Motivasi ini berbeda dengan motivasi untuk hidup aman dan tentram, karena motivasi ini timbul bilamana ada dorongan ingin mendapatkan pengalaman baru dalam hidup sekitar, baik dalam bentuk hubungan personal maupun impersonal. Dan motivasi yang mendorong mencari pengalaman baru adalah merupakan daya kekuatan psikologis yang membawa manusia kepada usaha pembaharuan dan perubahan.

\section{e. Motivasi dan Perilaku konsumsi}

Motivasi akan mempengaruhi perilaku seseorang begitu juga dalam hal konsumsi. Motivasi konsumen adalah keadaan didalam pribadi seseorang yang mendorong keinginan individu untuk melakukan kegiatan guna mencapai suatu tujuan. Dengan adanya motivasi pada diri seseorang akan menunjukkan suatu perilaku yang diarahkan pada suatu tujuan untuk mencapai sasaran kepuasan. Jadi motivasi adalah proses untuk mempengaruhi seseorang agar melakukan sesuatu yang kita inginkan. $^{35}$

Motivasi adalah hal yang menyebabkan, menyalurkan, dan mendukung perilaku manusia dalam kehidupannya. Kebutuhan dan tujuan dalam konteks perilaku konsumen mempunyai peranan yang sangat penting karena motivasi timbul karena adanya kebutuhan yang belum terpenuhi dan tujuan yang ingin dicapai. Kebutuhan dipandang sebagai salah satu penggerak dari perilaku konsumsi. Dalam hal ini berarti dapat disimpulkan bahwa motivasi akan mempengaruhi perilaku konsumsi dalam diri seseorang.

35 Nugroho J. Setiadi, Perilaku Konsumen perspektif..., hal. 27 
Pemanfaatan (konsumsi) merupakan bagian akhir dan sangat penting dalam pengolaan kekayaan, dengan kata lain, pemanfaatan adalah akhir dari keseluruhan proses produksi. 36 Setiap rangkaian produksi maka barang yang diproduksi akan bernilai jika barang tersebut dikonsumsi. Konsumsi yaitu menghabiskan dan menggunakan nilai guna suatu barang yang digunakan dalam kehidupan seharihari, konsumsi dapat berupa konsumsi suatu barang maupun konsumsi akan jasa. Bagi seorang muslim Al-Qur'an memberikan petunjuk dalam hal konsumsi AlQur'an mendorong agar manusia menggunakan barang-barang yang baik dan bermanfaat serta melarang adanya pemborosan dan pengeluaran untuk hal-hal yang tidak penting dan kurang bermanfaat.

Jadi dalam hal konsumsi masyarakat muslim diberi batasanbatasan dalam mengkonsumsi suatu barang atau jasa tidak mementingkan kepuasan, kesenangan semata namun terlebih juga harus memperhatikan

36 Afzalur Rahman, Doktrin Ekonomi Islam Jilid II (Yogyakarta: Dana Bakti Wakaf, 1995), hal. 17. unsur manfaat dari konsumsi yang kita lakukan. Jika melakukan konsumsi dengan baik maka manfaat yang besar akan diperoleh namun jika tidak dimanfaatkan/digunakan dengan baik maka akan mendatangkan keburukan (kemudharatan)

\section{KESIMPULAN}

Perilaku Konsumen dalam melakukan aktifitas konsumsi yang berlandaskan atas prinsip ekonomi secara islami sarat dengan nilai-nilai kerohanian yang secara tidak langsung mengarahkan konsumen agar tidak konsumtif dan tetap menjaga kemaslahatan bukan mengedepankan kesenangan dan kepuasan semata. lebih berorientasi kepada konsep kebutuhan (need) daripada keinginan (want).

\section{DAFTAR PUSTAKA}

Ahmad, Mustaq. 2001. Etika Bisnis dalam Islam. Jakarta: PustakaAl-kautsar

Arifin. 2009. Psikologi Dakwah Suatu Pengantar Islam. Jakarta: PT. Raja Grafindo Persada

Assobar. Al-Kitabul Akbar Al-Qur'an dan Terjemahannya. Jakarta Timur: Akbar Media

Doni, Rama. 2014. “ Tinjauan Ekonomi Islam Terhadap Perilaku Konsumen dalam Membeli Barang Di Pasar Panorama Zahara Busana Kota Bengkulu". skripsi 
sarjana, Jurusan Ekonomi Islam Fakultas Syariah dan Ekonomi Islam.

Fauzia, Ika Yunia., Abdul Kadir Riyadi. 2014. Prinsip Dasar Ekonomi Islam Perspektif Maqashid al-syari'ah. Jakarta: Kencana Prenada Media.

Hakim, lukman. 2012. Prinsip-prinsip Ekonomi Islam. Erlangga.

Isgiyanto,Awal.2009. tekhnik pengambilan sampel pada penelitian non eksperimental. Jogjakarta:Mitra cendikia press.

Jumantoro, Totok. Samsul Munir Amin. 2005.Kamus Ilmu Ushul Fikih. Amzah.

Karim, Adiwarman .2010. Ekonomi Mikro Islam edisi ketiga. Jakarta: Raja Grafindo Persada.

Masyuri, M.zainuddin. 2008. Metodologi penelitian pendekatan praktis dan aplikatif. Bandung: PT Refika Aditama.

Misbahul, Munir. 2007. Ajaran-ajaran Ekonomi Rasulullah kajian Hadits Nabi dalam Perspektif Ekonomi. Malang: Uin Malang Press.

Nurdin, Amiur. 2010. Islam Mazhab Swalayan. Bandung: Ciptapustaka Media Perintis.

Oktaviani,Felisia "Pengaruh Konsumerisme Gadget dikalangan Mahasiswa di Daerah Sekitar Solo".Felisiaoktaviani.blogspot.com/201 1/12/Pengaruh Konsumerisme gadgetdikalangan.html 22 desember 2014

Oktaviani, lia. 2011. "pengaruh label halal MUI terhadap pola konsumsi mahasiswa IAIN Bengkulu jurusan Syari'ah".
Skripsi sarjana, jurusan Syariah fakultas Syariah dan Ekonomi Islam.

Purwanto, Ngalim. 2006. Psikologi Pendidikan, Jakarta: PT Remaja Rosdakarya.

Pusat pengkajian dan Pengembangan Ekonomi Islam. 2011. Ekonomi Islam. Jakarta : PT. Raja Grafindo Persada.

Qardawi, Yusuf. 1997. Peran Nilai dan Moral dalam Perekonomian Islam. Jakarta: Rabbani Press.

Qardhawi, Yusuf. 2001. Norma dan Etika Ekonomi Islam. Jakarta:Gema insani.

Rahman, Afzalur.1995. Doktrin Ekonomi Islam Jilid II. Yogyakarta: Dana Bakti Wakaf.

Rianto, M.Nur., Euis Amalia. 2010. Teori Mikro Ekonomi Suatu PerbandinganEkonomi Islam dan Ekonomi Konvensional. Jakarta: Kencana Prenada Group.

Saleh, Abdul Rahma. 2004. Psikologi suatu pengantar dalam perspektif Islam. Jakarta: Prenada Media Kencana.

Sarwono, Henry., Danang Sunyoto. 2014. Pengantar ilmu Ekonomi Mikro teori dan soal. Yogyakarta: CAPS.

Setadi, Nugroho J. 2010. Perilaku Konsumen perspektif kontemporer pada motif, tujuan, dan keinginan konsumen. Jakarta: Kencana Prenada Media Group.

Suryani, Tatik. 2013. Perilaku konsumen di era internet. Yogyakarta: Graha Ilmu.

Sri Vinna,2016. Ekonomi Mikro syariah, Bandung: Pustaka Seti 